\title{
A Case of Giant Osteoma Located across the Parietal and Temporal Bones
}

\author{
Yee-Hyuk Kim, MD, PhD \\ Department of Otorhinolaryngology-Head \& Neck Surgery, Catholic University of Daegu School of Medicine, \\ Daegu, Korea
}

\begin{abstract}
- ABSTRACT -
Osteoma often develops in the skull and facial bones, most frequently in the paranasal sinuses, but rarely develops in the temporal bone. Temporal osteoma is most commonly seen in the external auditory meatus, followed by in the mastoid process. Although temporal osteoma can vary in size, it does not exceed $3 \mathrm{~cm}$ in most cases. In this case, a 64-year-old woman presented with a left-sided skull mass located behind the auricle that had grown gradually in size over the past 40 years. The mass was a giant osteoma exceeding $3 \mathrm{~cm}$ in diameter (maximum diameter, $3.2 \mathrm{~cm}$ ) located across the upper mastoid process, posterior temporal squama, parietomastoid suture, asterion, and inferior parietal bone. The lesion was successfully removed surgically. We report this case and review the related literature. (J Clinical Otolaryngol 2020;31:200-204)
\end{abstract}

KEY WORDS: Osteoma $\cdot$ Temporal bone $\cdot$ Parietal bone.

\section{Introduction}

Osteoma most often develops in the skull and facial bones, which are membranous bones. In the skull and facial bones, osteoma is most commonly found in the paranasal sinuses and only rarely in the temporal bone. ${ }^{1-}$

3) Temporal osteoma may arise in any part of the temporal bone, but it is most commonly seen in the mastoid process after the external auditory meatus. ${ }^{3-7)}$ Moreover, in general, osteomas grow gradually; although temporal bone osteoma can be of various sizes, it does not exceed $3 \mathrm{~cm}$ upon initial presentation in most cases. ${ }^{3,89}$ In the present case, a giant osteoma over $3 \mathrm{~cm}$ in diameter was found to involve the mastoid process, temporal squama, and parietal bone, in contrast to other commonly seen cases of osteoma limited to the temporal bone. Herein, we describe the case and its treatment.

\section{Case Report}

A 64-year-old female patient presented with a large lump on her head behind her left ear. She reported that the lump started to grow gradually in size approximately 40 years ago. The patient did not recall any trauma to the area where the lump was located. Although there was no pain at the site, it was difficult for the patient to wear glasses or hats due to the lump. The patient also complained of significant discomfort because the lump came in contact with the floor when she lay on her left side. In addition, the patient reported esthetic problems with regard to the limited hairstyles she could have. Although the lump grew very gradually, it continued to grow over a long period of time; the patient was thus concerned that it may be a serious condition and desired appropriate surgical treatment. On physical examination, a hard mass fixed to the skull was found behind

논문접수일: 2020년 8월 13일 / 논문수정일: 2020년 9월 23일 / 심사완료일: 2020년 11월 25일

교신저자: 김이혁, 42472 대구광역시 남구 두류공원로 17 길 33 , 대구가톨릭대학교 의과대학 이비인후과학교실

전화: (053) 650-4525 ·전송: (053) 650-4533·E-mail: yhukim@cu.ac.kr 
the left auricle, without any tenderness or erythema (Fig. 1). On the computed tomography (CT) scan of the temporal bone, a dome-shaped lesion with a wide base showing bone density with a maximum diameter of 3.2 $\mathrm{cm}$ was observed. The mass had developed in the outer table of the skull, and parts of the mass invaded the diploë (cancellous bone) of the skull in close proximity to mastoid air cells and inner table of the skull (Fig. 2). On the 3D CT scan of the skull, we observed a round, tall, protruding mass, which involved the upper mastoid process, posterior temporal squama, parietomastoid suture, asterion, and inferior parietal bone (Fig. 3). The surgery was performed under general anesthesia; the skin, subcutaneous tissue, and periosteum were lifted through a postauricular approach to expose the mass. The gross findings of the exposed mass largely coincided with the findings on the 3D skull CT scan (Fig. 4). The mass was removed using a chisel and surgical drill along with $2 \sim 3 \mathrm{~mm}$ of margin around the boundaries of the mass. For complete removal of the mass and prevention of recurrence, a surgical drill was used while removing the mass to make the inner table of the skull as thin as possible. When the superoposterior part of the mass was drilled using the surgical drill, significant

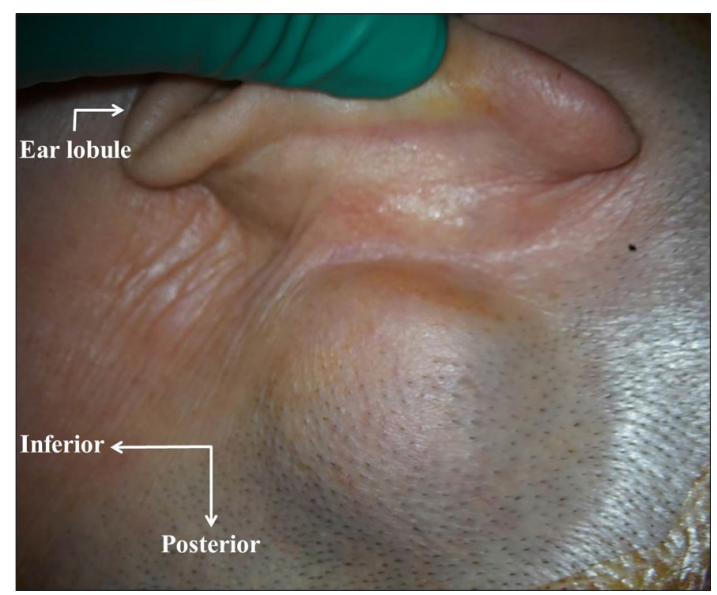

Fig. 1. Pre-operative findings of the mass. A large, round, hard mass fixed to the skull was found behind the left pinna. bleeding was noted, which was thought to have been caused by damage to the transverse sinus. The bleeding was successfully controlled using bone wax (Fig. 5A). The mass was divided into three parts for removal due to its large size (Fig. 5B). Pathological findings indicated typical findings of osteoma as characterized by the mature bone tissue, Haversian canals, and dense lamellae (Fig. 6). The patient did not have any specific complications 7 months after the surgery. Physical examination was performed during outpatient follow-ups, and there were no signs of relapse.

\section{Discussion}

Osteomas are benign tumors that develop and gradually enlarge in the craniofacial bone, which is a membranous bone. Osteomas commonly occur in the paranasal sinuses and are often asymptomatic; therefore, are generally discovered incidentally. On the other hand, osteomas in the skull, including the temporal bone, are rare but may cause aesthetic problems. ${ }^{1-3)}$ These tumors are rare prior to puberty, and the incidence is known to be twice as high in women than in men. ${ }^{2)}$ The present case had the general features of osteoma as described above. Histologically, osteomas are categorized into compact, spongiotic, and mixed types. The compact type characteristically shows Haversian canals and dense lamellae, thus resembles well-differentiated, mature bone. The spongiotic type characteristically shows spongiotic bone and fibrous cellular tissue and resembles bone marrow, while the mixed type demonstrates characteristics of both the compact and spongiotic osteomas. The present case was histologically categorized as the compact type. ${ }^{2-4)}$

Our literature review revealed that osteoma limited to the temporal bone is often surgically treated for esthetic reasons. ${ }^{2,10-15)}$ The osteoma in the present case was large in size (a giant osteoma with maximum diameter exceeding $3 \mathrm{~cm}),{ }^{16,17)}$ and was located across the superior 

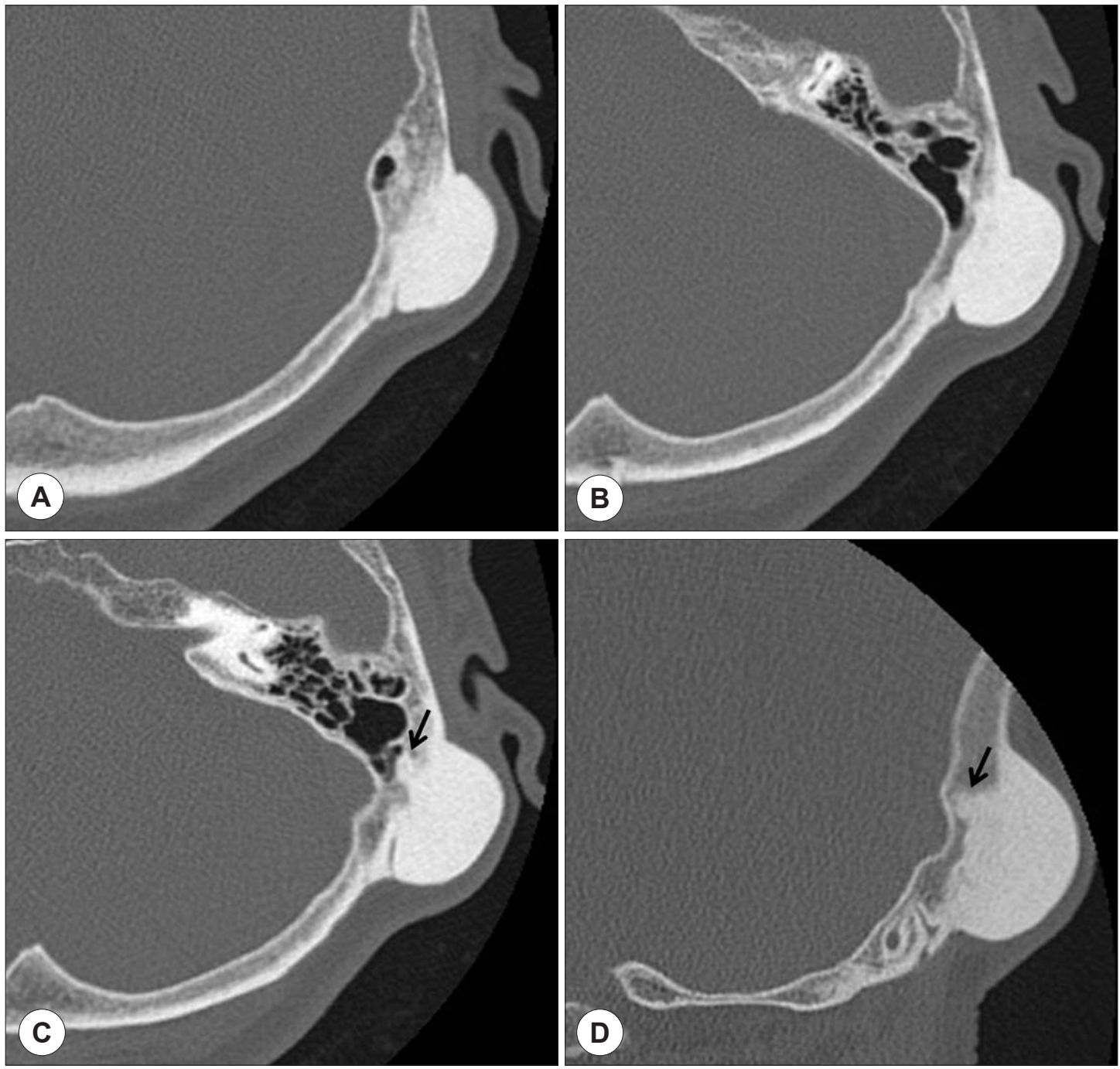

Fig. 2. Pre-operative findings on the temporal bone CT scan (A, B, C: axial views, D: coronal view). A : Findings of the mass at the level of the transverse sinus. B : Findings of the mass at the transition between the transverse and sigmoid sinuses. C : Sigmoid sinus is shown on the image, and the bone density of the osteoma passes the diploë of the temporal bone and reaches the mastoid air cells (arrow). D : The bone density of the mass invades deep into the skull close to the inner table (arrow).

temporal bone and inferior parietal bone. Due to its size and location, the osteoma invaded higher into the skull than an osteoma limited to the mastoid process. Therefore, the patient had more difficulties when she wore glasses or hats than patients with osteoma limited to the mastoid process. Moreover, the mass was located at a site that would come in contact with the floor when lying on her side; accordingly, the patient would have experienced even more discomfort when lying on the affected side because pressure would have been placed on the mass on her head. Since the lesion was located superior to the mastoid process, possible damage to the sigmoid sinus and transverse sinus required caution during surgery. The skull around the transverse sinus is 


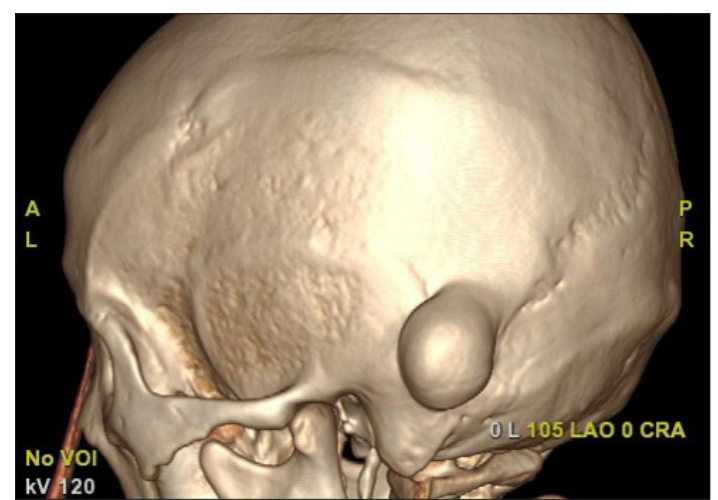

Fig. 3. Pre-operative findings of the mass on the $3 D C T$ scan of the skull. A round, tall, protruding mass that involves the upper mastoid process, posterior temporal squama, parietomastoid suture, asterion, and inferior parietal bone can be observed.

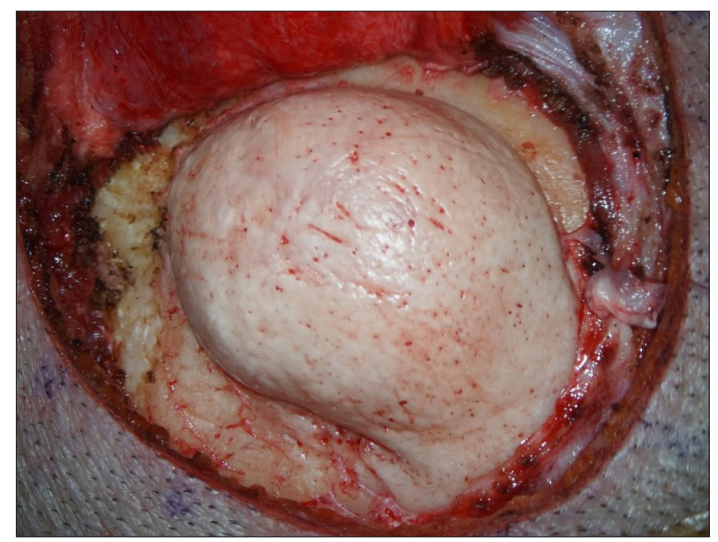

Fig. 4. Intraoperative findings of the mass. The gross findings of the mass noted during surgery largely agreed with the 3D CT findings of the skull.

thin, and the transverse sinus is located medial to this relatively thin part of the skull. Therefore, significant bleeding may have occurred from damage to the transverse sinus while drilling to thin the inner table of the skull. In the present case, significant bleeding was noted while drilling to remove a 2 3-mm margin around the boundary of the osteoma.

Osteoma is often treated through surgical resection, and post-operative recurrence is very rare. , $, 4,10,12,13,18,19)^{2}$ When osteoma is located on the temporal squama or mastoid process, a complete resection should be per-
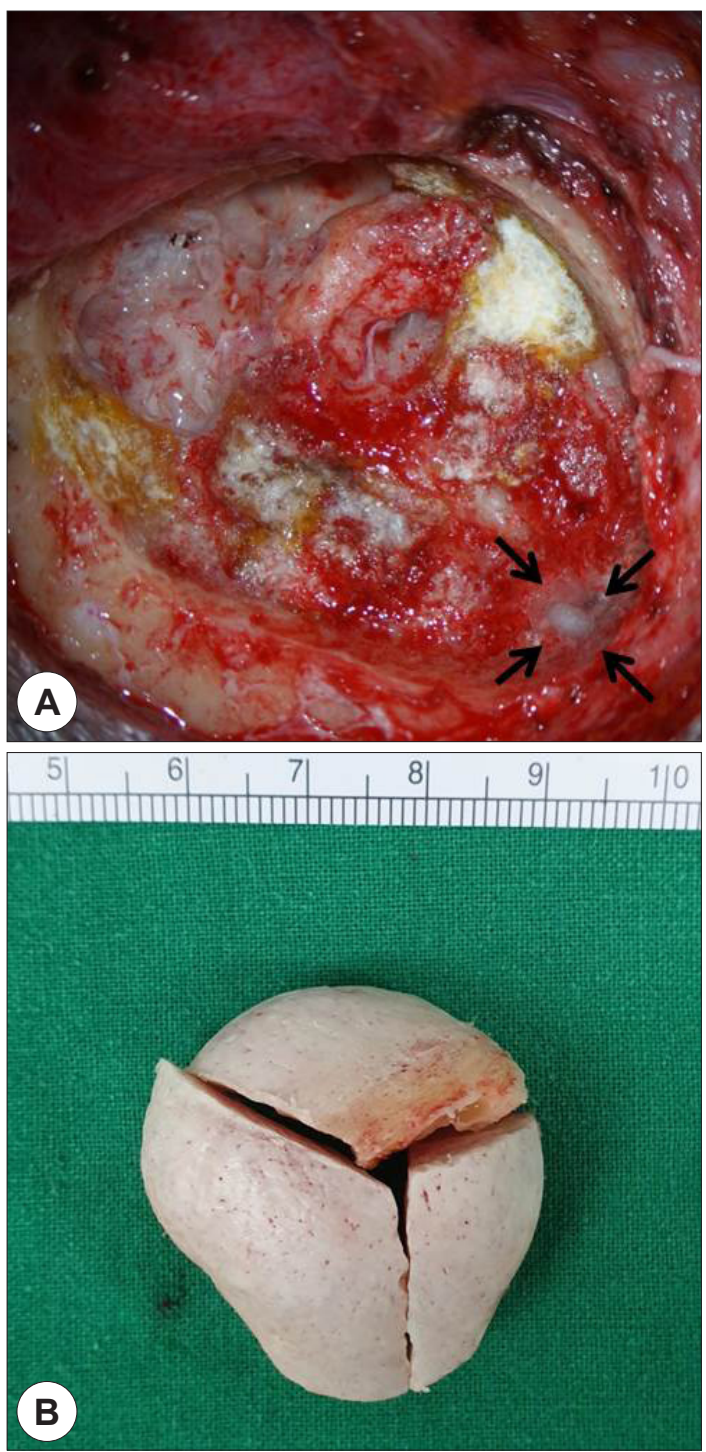

Fig. 5. Photograph of the surgical site after mass removal (A) and gross findings of the removed mass (B). A : Severe bleeding stopped using bone wax (arrows). B : The mass was removed in three parts due to its large size.

formed until normal mastoid air cells are exposed or the base of the osteoma should be removed until cortical bone without osteoma is confirmed. ${ }^{10,12,13,15,20)}$ In the present case, the exact location of the osteoma in the skull and the overall shape of the osteoma could be easily assessed on the 3D CT scan of the skull, and the 3D 


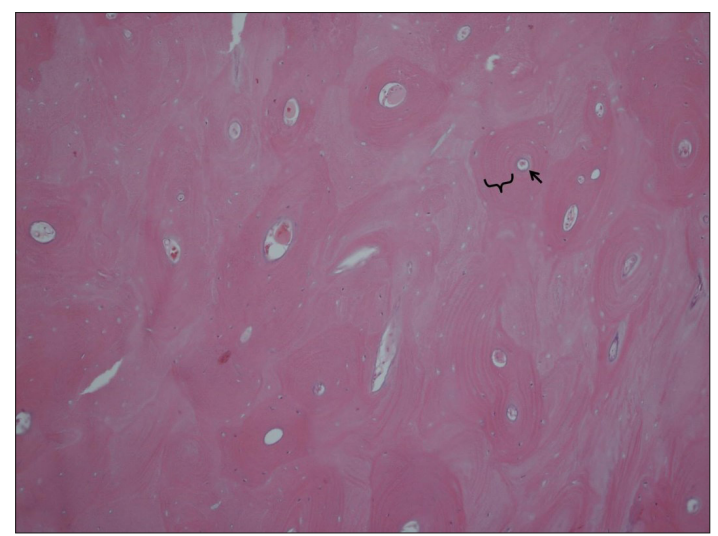

Fig. 6. Pathological findings (H\&E stain $\times 100)$. Mature bone tissue, Haversian canals, dense lamellae surrounding Haversian canals, and flattened lacuna-containing osteocytes can be seen. The arrow $(\rightarrow)$ shows the Haversian canal and curly bracket (\}) shows the dense lamellae.

CT findings of the skull largely coincided with the gross findings of the osteoma noted during surgery. Temporal bone $\mathrm{CT}$ scan showed that the osteoma developed in the outer table of the skull; however, parts of the osteoma invaded past the diploë close to the mastoid air cells and inner table of the skull. Therefore, for complete removal of the osteoma, some mastoid air cells were exposed, and the base of the osteoma was removed by thinning the inner table of the skull as much as possible. The overall external appearance of the osteoma was assessed on the 3D CT scan of the skull, and the overall scope of the resection was planned based on the CT findings. Temporal bone CT scan was used to assess the degree of invasion into the diploë of the skull, and the depth of skull resection was planned based on this assessment.

\section{REFERENCES}

1) Sheehy JL. Diffuse exostoses and osteoma of the external auditory canal: a report of 100 operations. Otolaryngol Head Neck Surg 1982;90(3 Pt 1):337-42.
2) Yum JH, Park SN, Yeo SW, Suh BD. A case of osteoma originated from the squama of temporal bone. Korean J Otolaryngol-Head Neck Surg 2002;45(9):915-7.

3) Denia A, Perez F, Canalis RR, Graham MD. Extracanalicular osteomas of the temporal bone. Arch Otolaryngol 1979;105(12):706-9.

4) Lee JD, Park HS, Kwak DH, Youn SH. A osteoma of the external auditory canal. J Clinical Otolaryngol 2002;13(2):213-5.

5) Choi WC, Kim SK, Park MK, Lee SY. A case of mastoid osteoma. Korean J Otolaryngol-Head Neck Surg 2002;45(6):617-9.

6) Rhee GS, Koo SY, Cho SH, Chung CS, Ko KL. A case of osteoma of the temporal bone. Korean J Otolaryngol-Head Neck Surg 1984;27(1):66-9.

7) Kim CW, Jeon SH, Kim JG, Lim JS, Yang JS. Osteoma of the temporal bone. Korean J Otolaryngol-Head Neck Surg 1988;31(6):1020-2.

8) Kuzniar A, Staniczek J, Kulicz A. A case of giant osteoma of temporal bone. Pol Tyg Lek 1969;24(37):1413-4.

9) Guérin N, Chauveau E, Julien M, Dumont JM, Merignargues G. Osteoma of the mastoid: apropos of 2 cases. Rev Laryngol Otol Rhinol (Bord) 1996;117(2):127-32.

10) Kim YM, Koo BS, Park CI, Park YH. Osteoma: presenting as a retroauricular mass. Korean J Otolaryngol-Head Neck Surg 2005;48(10):1274-6.

11) Viswanatha B. Extracanalicular osteoma of the temporal bone. Ear Nose Throat J 2008;87(7):381-3.

12) Park SJ, Kim YH. A case of giant osteoma developed from the mastoid cortical bone. Korean J Audiol 2012;16(2):95-8.

13) Karataş A, Cebi IT, Yanık T, Koçak A, Selçuk T. Osteoma originating from mastoid cortex. Turk Arch Otorhinolaryngol 2017;55(1):48-50.

14) Akamatsu T, Tanaka R, Fukui T, Miyasaka M, Yamada S. A case of mushroom shape temporal bone osteoma. Tokai $\mathrm{J}$ Exp Clin Med. 2009;34(3):87-91.

15) Güngör A, Cincik H, Poyrazoglu E, Saglam O, Candan H. Mastoid osteomas: report of two cases. Otol Neurotol 2004;25(2):95-7.

16) Fobe LP, Melo EC, Cannone LF, Fobe JL. Surgery of frontal sinus osteoma. Arq Neuropsiquiatr 2002;60(1):101-5.

17) Udovicki J, Milosevic D, Dubljevic L. Giant osteomas of the paranasal sinuses. Med Pregl 1991;44(11-12):467-470.

18) Fleming JP. Osteoma of the mastoid. Can J Surg 1966;9(4):402-5.

19) Probst LE, Shankar L, Fox R. Osteoma of the mastoid bone. J Otolaryngol 1991;20(3):228-30.

20) Jeong J, Choi YJ, Hong CE, Shin HA. Giant osteoma in the mastoid of the temporal bone: complete excision of a rare tumor. Otol Neurotol 2018;39(9):e894-6. 